\section{Grundig og godt om problematferd blant ungdom}

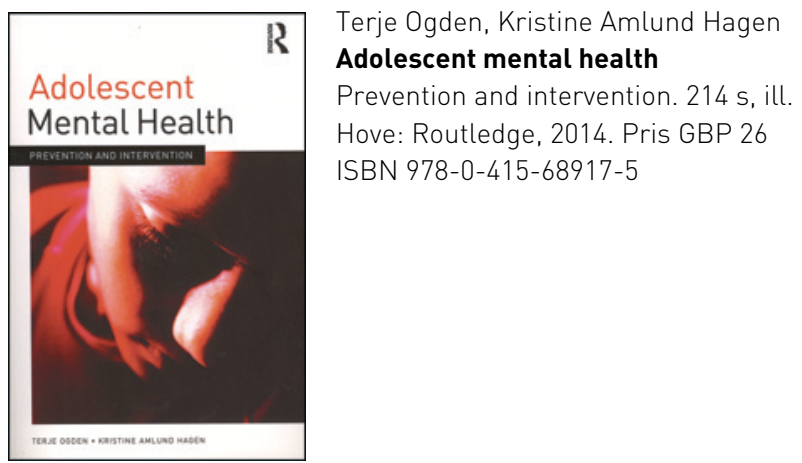

Hvordan skal vi forstå at noen ungdommer utvikler problematferd og emosjonelle vansker, og hva viser aktuell forskning er virksomme tiltak for å forhindre eller rette på en slik utvikling?

Denne boken belyser disse spørsmålene. Den sosialøkologiske modellen, som beskriver problematferd og emosjonelle vansker som et resultat av samspill mellom individet og forhold i omgivelsene (familie, venner og skole/fritid), er sentral i forfatternes forståelse av hvordan vansker utvikles og opprettholdes, og gir også implikasjoner i forhold til forebyggende tiltak og intervensjoner. Det gjennomgående perspektivet er å ta utgangspunkt $\mathrm{i}$ ungdommens og familiens egne ressurser, og metodene som implementeres, er familie- og nærmiljøbaserte. Det beskrives tiltak som tar utgangspunkt i nyere evidensbasert forskning, og ulike intervensjoner belyses ved hjelp av kasuistikker. Ettersom det er et mål å forebygge atferdsproblemer så tidlig som mulig, beskrives tiltak overfor både barn og ungdom.

Tittelen Adolescent mental health skaper forventninger om en gjennomgang av de viktigste psykiske lidelsene hos barn og unge. Det gir denne boken ikke. I kapitlet om internaliserende problemer beskrives depresjon og angst. For øvrig er det stort sett eksternaliserende problemer i form av atferdsvansker og rus som er tema. I og med at begge forfatterne er eller har vært tilknyttet Atferdssenteret, er et slikt fokus ikke overraskende, og man kan anta at boken er skrevet spesielt med tanke på terapeuter og andre som arbeider med barnevernstiltak, atferdsmodifiserede tiltak og rusomsorg. Undertegnede savner likevel mer fokus på problematferd som i større grad er forbundet med internaliserende problemer, spesielt selvskading, som er en vesentlig utfordring også innenfor barnevernsfeltet.

Når det er sagt; boken anbefales på det sterkeste til alle som jobber med barn og unge som er i risiko for eller har utviklet problematferd. Den er forbilledlig i måten den kritisk gjennomgår eksisterende tiltak på, og den er tankevekkende og bevisstgjørende med hensyn til større grad av differensiering av tiltak - hvilke tiltak virker for hvem? Gjennomgående bruk av kasuistikker gjør det lett å relatere til egen praksis. Boken er inspirerende og gir grunnlag for optimisme. Konklusjonen etter å ha lest boken er at forebyggende tiltak og behandling av problematferd nytter, og at en viktig forutsetning er rett intervensjon til rett tid på rett sted.

Ruth-Kari Ramleth

Stipendiat, Nasjonalt senter for selvmordsforskning og -forebygging

\section{Ernæring, molekyler og forebygging av hjerte- og karsykdom}

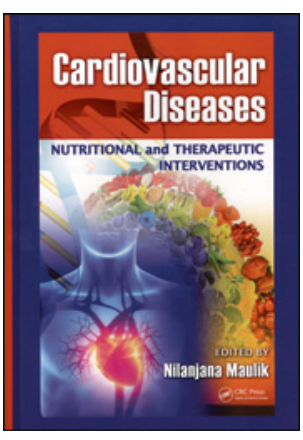

Nilanjana Maulik, red.

\section{Cardiovascular diseases}

Nutritional and therapeutic interventions. 586 s, tab, ill. London: CRC Press, 2013. Pris GBP 93

ISBN 978-1-4398-8200-9

Bokens hovedredaktør er indisk, men arbeider i USA. Hun og hennes 72 medforfattere har ønsket å samle dagens kunnskap om mulighetene for å manipulere hjertets molekyler og biokjemi ved hjelp av kosthold og kosttilskudd. Boken handler med andre ord ikke om sykdommer og ikke om terapi i form av medikamenter, kirurgi eller kateterintervensjon. Dens budskap er at det kanskje finnes alternativer til alt dette, særlig for forebygging, i form av mer globalt tilgjengelige og konvensjonelle midler.

Forfatterlisten har et asiatisk-amerikansk preg: 31 er fra USA, de fleste med asiatiske navn, 13 er fra India, 5 fra Kina og bare 7 fra Europa. Boken er velredigert og ryddig. Den starter med et elementært kapittel om epidemiologi, og dessverre starter nesten alle de øvrige 30 kapitlene med å gjenta deler av dette. Referansene er meget fullstendige, nesten «hypertrofiske», idet 161 av de 586 sidene er referanser. Til gjengjeld er indeks meget sparsommelig, hvilket er beklagelig for et slikt referanseverk.

Det er kapitler om alle typer kosthold og tilskudd, som vitaminer, linfrø, hvitløk og kurkumin, men ikke om fisk. I tillegg kan vi lese om yoga, trening og alkohol. Nesten alle de omtalte faktorene virker tilsynelatende antioksidativt, og teorien om de skadelige frie oksygenradikalene gjentas til kjedsommelighet. Det er liten åpning for at det kanskje kan være både for lite og for mye oksidasjon, og at det ikke er lett å si når det ene eller det andre er best.

De metabolske detaljene i boken ligger utenfor mitt kompetanseområde. Konklusjonene når det gjelder de kliniske konsekvensene, er imidlertid beskjedne og avbalanserte. Nesten alle kapitlene slutter med et ønske om kontrollerte studier på dette feltet.

Det er få henvisninger til norske kilder. Flere refererer imidlertid til vår NORVIT-studie av effekten av vitamin $\mathrm{B}$ på pasienter med gjennomgått hjerteinfarkt. Hypotesen om betydningen av å senke homocysteinnivået med folinsyre dukker likevel opp gjentatte ganger. Det virker urimelig at de som formulerer slike hypoteser, ikke endrer fremstillingen når store kliniske forsøk viser at dette ikke fungerer.

Siden boken stort sett handler om udokumenterte muligheter for forebygging og behandling, egner den seg nok først og fremst for forskere innen patofysiologi, epidemiologi og klinikk som ønsker ideer til nye forsøk, særlig store kontrollerte intervensjoner. Her er mange ukjente muligheter og gode ideer. Først og fremst hører den hjemme som et referanseverk i laboratoriet.

Knut Rasmussen

Professor emeritus, Universitetet i Tromsø 